Jakub Z. Lichański*

\title{
The Rhetoric of Popular Science Texts. Scientific American Magazine as a Typical Example
}

\section{Introduction $^{1}$}

The following text considers two problems: the first is connected with the "Scientific American" periodical, the other - with popular science texts. While the first issue is relatively simple, the second one may pose certain difficulties even at the level of describing the problem. I shall therefore begin with the first matter, since it is less troublesome.

Even though the "Scientific American" magazine is fairly popular, it does require at least a brief introduction. It has been published since 1845, when it bore the subtitle: The Advocate of Industry and Journal of Scientific, mechanical and Other Improvements. It was issued as a four-page weekly newspaper ${ }^{2}$. It should be emphasized that it also included information from the U.S. Patent Office. In 1860, its layout was redesigned and the subtitle was changed to: A Journal of Practical Information in Art, Science, Mechanics, Agriculture, and Manufactures. The design was revamped at least two more times - in 1948 and subsequently in 1986. The magazine's character also evolved; its present-day shape has been developed in the course of consecutive changes of editors and due to the technical advancement of print.

Currently, "Scientific American" has 18 foreign-language editions (and editorial teams) and its scope is international. This evolution began as early as in 1890, when a Spanish-language edition "La America Cientifica" was released.

\footnotetext{
* Prof. dr hab., e-mail: postmaster@lichanscy.atomnet.pl; The University of Warsaw, Faculty of Polish Studies, Institute of Applied Polish Studies, Department of Rhetoric and Media; ul. Krakowskie Przedmieście 26/28, 00-927 Warszawa.

${ }^{1}$ Basic information is available on the following website: http://en.wikipedia.org/wiki/Scientific_American [access: 26.02.2015]; B.V. Lewenstein, "Magazine Publishing and Popular Science After World War II", American Journalism 1989, No. 6 (4), pp. 218-234; B.V. Lewenstein, "The Meaning of 'Public Understanding of Science' in the United States after World War II", Public Understand Science 1992, No. 1, pp. 45-68.

${ }^{2}$ It began as a one-page leaflet!
} 
The present, relatively open, format of the magazine was de facto created quite late - after World War II.

The range of issues tackled by popular science literature and the ability to analyse them using rhetorical devices constitute an entirely different problem. The fundamental issue may be roughly explained as follows:

Popularization of science (popularization of knowledge) - activities aimed at making the results of scientific research accessible and presenting the problems of science to a wide audience - Is undertaken outside of the education system as its complementation and enrichment. The main forms of popularization of science comprise popular science books as well as publications and programmes in the press, radio, television and internet ${ }^{3}$.

Thus, the goal is to make the results of scientific research accessible in order to popularize through popular science publications. Which is absolutely right, but involves an idem per idem error. I believe that the problem consists in the meaning of the concept "popularization", which is supposed to denote some feature of a publication. According to the dictionary definition, it means "making something popular [= widely liked, increasingly popular; sough-after, valued by the general public; accessible, understandable; simple, easy - emphasis by J.Z.L]. POPULARIZER - one who makes knowledge accessible to the general public by writing understandable books and articles, and delivering such speeches"4.

In this way, we defined the subject of our discussion. It concerns a text which is characterized by being understandable to the general public. Therefore, the goal is to determine the level of information, contained in a text, which does not require specialist knowledge (Seyle). From the rhetorical point of view, the feature of comprehensibility applies to elements such as:

At the stage of inventio - the way of presenting a problem that is clear and relates to opinio communis, and argumentation which avoids controversy, but is simultaneously unambiguous and simple.

At the stage of dispositio - the use of clear and organized argumentation as well as the methods of presenting issues which are familiar from school education.

At the stage of elocutio - vocabulary that does not conjure up so-called professional jargon, and in the compositional sphere - simplicity and clarity. Also the introduction of illustrations, infographics, colour differentiation, etc. This last element is the stage of pronuntiatio, and in the modern form - of text presentation.

\footnotetext{
${ }^{3}$ http://pl.wikipedia.org/wiki/Popularyzacja_nauki [access: 27.03.2015].

${ }^{4}$ M. Arct, „Słownik ilustrowany języka polskiego”, Vol. 2, Wydawnictwo M. Arcta, Warsaw 1916, p. 228.
} 
Therefore, popularization is - from the rhetorical point of view - a structure of both the argumentative sphere of a text and its composition, as well as vocabulary that corresponds to the way of perceiving new information from widely understood knowledge/science, which was shaped at the stage of school education or undergraduate level.

\section{Formulation of the problem}

At the end of the previous part of these considerations, I defined basic problems which we should further examine in detail.

At the inventive stage - it is, apart from the indicated issues, also the range of subjects which will interest the so-called wider audience and the argumentation used while presenting a subject: it should include, among other things, the use of photographs and infographics, and introduce basic secondary sources.

At the dispositional stage - the arrangement of the entire text, which should be as simple and understandable as possible for a non-specialist.

At the elocutional stage - the choice of stylistic devices (e.g. colours, typeface, size of photographs or infographics, so-called highlighted information), vocabulary, the composition of the entire text.

Two stages - the art of memory and presentation - are subordinate to the previous ones and repeat the already established solutions.

The obvious and recurring structure of every issue is immensely important in this situation; here is an example: 
Phot. 1 an example of editorial pages in "Scientific American"

\section{SCIENIIIIC SWIATNAUKI AMERICAN \\ Luty 2015 nr 2 (282)}

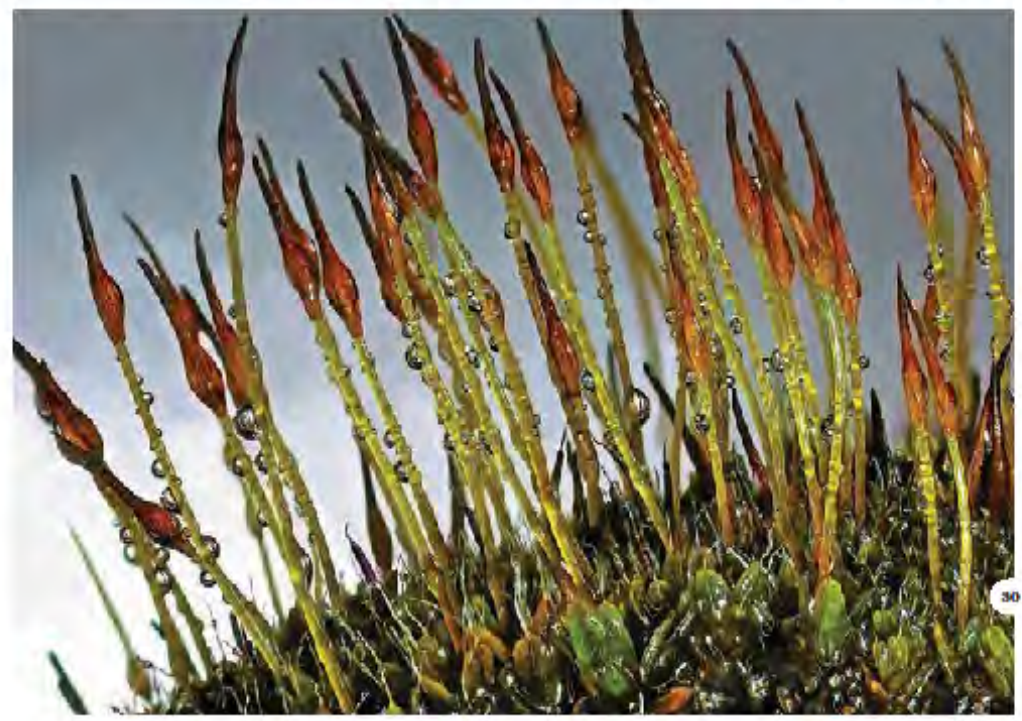

ARTYKULY

ASTRONOMIA

92 Lepsze nik Ziemia

Najdogodnicjøsymi miejsoumi đo życia

we Wreochtwiecie mog̨ okat.af sic planety znacznie rózinique siç od nasrej.

Renk Heller

BIOLOGIA

so Kycie w powiększenitu Mikroskopy odnajđujia Dickno w nienceckiwanych

micjseach.

Kate Wong

MEDYCYNA

38 Bél, ktéry nie chee minace

Palqay. łamiqcy. Presszywaiqcy. Niezależnie od postaci

pruewlekly bol moxic atrzynywać siç mimo lecrenia.

Sw icie spojrzenic na jego przyczyny jorwadei

do nowych ponysiliw na jego joknonanie.

Stephani Sutherland
EKSPLORACIA

46 Na tropie zatopionych skarbów

Nowe trehniki umozliwiajq archeologom prowadzenie badah rơwnie precyayjuic, jak na ląteic. Philip J.Hills

ASTRONOMIA

a4 Poszukiwanie skamienialośc

w Drodze Mlecznej

Grue kosmieny dostareza nowych wskarefwek dotycracych nowstania naszego rakatka Wezechlowiata Kathryn V. Jahnston ZYWNOSC

60 Cay przetrwa czar pinot noir? Jak zachowat smak wina mimo zmian klimatn. Kimberiy A. Nichalas

ARCHEOLOGIA

68 Opowiésé boga burzy Nawo odkryty fryz Majiow rmaca fwiatlo na burrliwa historiç staroxytnej eswilizaçi. Zach Zorich

Source: http://en.wikipedia.org/wiki/Scientific_American 2015-02-26 [access: 27.03.2015]. 
This also includes elements such as:

\section{REGULAR COLUMNS}

\section{Science Agenda}

How to cool a planet

By the Editors

\section{Scanner}

Is a planetoid worth catching. Healthy tricks of bears.

Do not blackmail children! How name determines one's fate. In theory they are, in practice they are not. Energy no matter from where. Fabrics worth one's life.

Power your pacemaker yourself. Musical laboratory.

Virtual reality cures phobias.

\section{Forum}

The end of economic growth?

Carl Benedikt Frey

\section{TechnoFiles}

You - in numbers

David Pogue

\section{Health}

Sometimes it is better not to ask

Dina Fine Maron

\section{Skeptic}

Here Be Zombies

Michael Shermer

\section{Anti Gravity}

The problem of great gravity

Steve Mirsky

\section{Graphic Science}

Who, where and on what subject

Mark Fischetti

\section{Ex libris}

78 Good to know

\section{0 "Scientific American" files}

I draw attention to the fact that the presented structure of subsequent issues ensures that the reader will be certain of finding something interesting in every number. And, additionally, it will be provided in a form that is accessible, but also guarantees the high scientific quality and professionality of information.

However, we must also examine the audience. The differentiations made by Jackie Mardikian and Lisa Vecchioli from the library of Rutgers University in 
New Jersey, USA ${ }^{5}$, may be helpful; they juxtaposed the features of different kinds of periodical publications, distinguishing between popular, scientific and professional literature: some of these remarks may also be referred to fiction ${ }^{6}$ :

Tabele 1. Types of periodicals and scientific literature

\begin{tabular}{|c|c|c|c|}
\hline Purpose & Popular & Scientific & Professional \\
tain the general reader & $\begin{array}{c}\text { To communicate research } \\
\text { and scholarly ideas }\end{array}$ & $\begin{array}{c}\text { To apply scientific } \\
\text { information; to predict }\end{array}$ \\
\hline Audience & General public & Other scholars, students & $\begin{array}{c}\text { Practitioners in the } \\
\text { field, professionals }\end{array}$ \\
\hline Publisher & $\begin{array}{c}\text { Broad variety of public } \\
\text { interest topics, cross } \\
\text { disciplinary }\end{array}$ & $\begin{array}{c}\text { Very narrow and specific } \\
\text { subjects }\end{array}$ & $\begin{array}{c}\text { Information relevant } \\
\text { to field and members } \\
\text { of a group }\end{array}$ \\
\hline Writers & $\begin{array}{c}\text { Commercial } \\
\text { freelancer (includ- } \\
\text { ing journalists and } \\
\text { scholars) }\end{array}$ & $\begin{array}{c}\text { Professional associa- } \\
\text { tions; academic institu- } \\
\text { tions; sometimes - com- } \\
\text { mercial publishers }\end{array}$ & $\begin{array}{c}\text { Professional, occupa- } \\
\text { tional, or trade group }\end{array}$ \\
\hline
\end{tabular}

Source: J. Mardikian, L. Vecchioli, Popular Literature vs. Scholarly Peer-Reviewed Literature. What's the Difference?, http://www.libraries.rutgers.edu/rul/indexes/scholarly_articles.shtml [access: 23.03.2010].

This comparison is illuminating, since it not only makes one realize the differences, which describe recipients, but also specifies the aims and contents, the qualifications of writers, the way in which contents are conveyed and, finally, the frequency of publishing texts. This concerns the main subject of our interest, that is periodicals. Slightly different ones are included here, namely: "Time", "US News and World Report", "Modern Healthcare" in the first group ("Scientific American" may also be listed in this category); "Journal of Acquired Immune Deficiency Syndrome" in the second group and "Institute of Transportation Engineers Journal" in

${ }^{5}$ Cf. J. Mardikian, L. Vecchioli, "Popular Literature vs. Scholarly Peer-Reviewed Literature. What's the Difference?", http://www.libraries.rutgers.edu/rul/indexes/scholarly_articles.shtml [access: 23.03.2010].

${ }^{6}$ Ibid. This comparison omits the issue of styles characteristic of given types of writing, matters connected with the frequency of releasing publications, and with examples (the last ones correspond exclusively to American examples, which a Polish recipient may find insufficiently distinct). 
the third. The issues concerning five initial distinguishing features: purpose, audience, coverage, publisher and writers are especially noteworthy.

The above table should, however, be treated as a point of departure for arranging a pattern connected with the subject of our considerations. I draw attention to the fact that the division, which is supposed to distinguish the types of periodical publications, makes it possible to capture the features belonging to the problem in question, that is the popularization of knowledge. The Audience category, in a sense, combines all types of recipients, and it is difficult to divide it as proposed. What is more, the popularization of science (education), again: in a sense, equalized the knowledge of recipients; the difference may only be at the level of philological competences - which must be noted.

I also emphasize that the category of coverage in the first group presents the interests and competences of the recipient. This is also connected with the aforementioned popularization; it leads to the fact that - perhaps only in subjective opinion - the recipient considers himself as fully competent to evaluate the contents presented by the author/ authors of cultural texts. We are therefore dealing with a situation which was described, with reference to entirely different issues, by Harry Frankfurt in his famous study On bullshit?.

\section{Discussion of the presented problem}

I am, obviously, aware that I should describe and analyse some articles. I shall not do so, since I assume that the discussed periodical is well-known. However, it seems that what was already said may cause certain doubts.

The first one concerns the general use of rhetorical devices to describe a problem. They were not demonstrated in practice, only how they should be applied, and to what fragments of texts, was indicated. Yet the fragment of the number from February 2015, cited in the form of an illustration, already shows that the presented research suggestion is correct. Firstly - the illustration contains a certain piece of information which refers to the second article, and serves as a good introduction to its content. The lead, which is provided after the title ("Microscopes find beauty in the most unexpected places"), implies what the content of the article entitled Life under the lens is. Therefore, the basic message of the text is suggested before we even start reading.

The same principle applies to the remaining texts. The titles of essays, which appear in regular columns, also include elementary information regarding their

\footnotetext{
${ }^{7}$ Cf. H. Frankfurt, „O wciskaniu kitu”, transl. H. Pustuła, Wydawnictwo Czuły Barbarzyńca, Warsaw 2008.
} 
contents. Sometimes in the form of a synecdoche or metonymy - and these are the only fragments which require any intellectual effort from the recipient.

The issue of the contents of articles is more complicated. It should be kept in mind, however, that each of them has identical structure. The title is followed by a very brief summary of the basic problems that will be discussed. At the end, a scarce bibliography is provided (usually three or four positions) for further, independent reading. As I mentioned, the text usually contains illustrations, drawings, tables, graphs, etc. - elements of an infographic character, which make it possible to present the problems in question in an easier way. These are elements of the use of the principles of visual rhetoric. In accordance with the tradition of both Kenneth Burke and Sonja K. Foss, this is the skilful use of "a system of symbols used by mankind, including, e.g. various images"

Do they fulfil the basic assumptions? That is to say, are they understandable to the general public (which, according to Marian Arct, is supposed to determine whether they belong to popular texts)? The answer is positive, and it partially results from the previously mentioned illustration presenting the table of contents of a particular number, here: from February 2015. This is determined by the manner of formulating leads (and their appearance near titles of articles - which is out of the question in a scientific magazine). The way of providing very brief information concerning the content of an article, e.g. : (1) Microscopes find beauty in the most unexpected places (title: Life under the lens), (2) New techniques enable the archaeologists to conduct research as precisely as on land (title: On the trail of underwater treasures) - shows that we are dealing with information, and not only, for example, an advertisement. Simultaneously, their function is to either expand the information - example (1), or explain the metonymic form of the title.

\section{Conclusions}

In conclusion, it might be claimed that texts published in popular science magazines are rhetorized so that:

- problems are presented in a clear and convincing way;

- if there are doubts, they are formulated as obvious issues to be explained;

- information is not provided in modal forms but, as in the case of, e.g. leads, in the form of assertion;

- information (and the very articles and essays) is usually either explanatory

${ }^{8}$ K. Burke, "Language as Symbolic Action. Essays on Life, Literature, and Method", University of California Press, Berkeley 1966, p. 28; S.K. Foss, "Theory of Visual Rhetoric", in: "Handbook of Visual Communication. Theory, Methods, and Media", ed. K. Smith, S. Moriarty, G. Barbatsis and K. Kenney, Lawrence Erlbaum, Mahwah, New Jersey 2005, p. 141 nn. 
or descriptive; in the second case, it presents facts (without stating whether they are established, confirmed and explained or only established);

- all elements of visual rhetoric are repeatedly used, including, among other things, illustrations, infographics, colours;

- the composition of articles is "fixed" and includes at least three permanent elements: a) the summary of basic information, b) visual material, c) basic bibliography of the issue.

In the case of works such as articles or essays in "Scientific American", rhetoric determines mainly not the elocutional features (although they are important) but, above all, the unique compositional features of both the entirety of the number and individual articles or essays. They obviously differ in terms of their subjects, however, the compositional pattern they realize is identical.

They fulfil the fundamental principle of the theory of rhetoric, which derives from Aristotle himself: in order to convincingly talk about any problem, we must perform one task - we must present it in such a way that our recipient receives reliable and uncontroversial information - this is a paraphrase of the remarks from Rhetoric and Nicomachean Ethics. After all, in the latter we read that:

In the same spirit, therefore, should each type of statement be received; for it is the mark of an educated man to look for precision in each class of things just so far as the nature of the subject admits; it is evidently equally foolish to accept probable reasoning from a mathematician and to demand from a rhetorician scientific proofs'.

The authors and editors of "Scientific American" act in this way, which I have attempted to demonstrate.

\section{Bibliography}

Arct M., „Słownik ilustrowany języka polskiego”, Vol. 2, Wydawnictwo M. Arcta, Warsaw 1916. Aristotle, „Etyka nikomachejska”, transl. D. Gromska, Państwowe Wydawnictwo Naukowe, Warsaw 1956.

Burke K., "Language as Symbolic Action. Essays on Life, Literature, and Method", University of California Press, Berkeley 1966.

Foss S.K., "Theory of Visual Rhetoric", in: "Handbook of Visual Communication. Theory, Methods, and Media”, ed. K. Smith, S. Moriarty, G. Barbatsis and K. Kenney, Lawrence Erlbaum, Mahwah, New Jersey 2005, pp. 141-152.

Frankfurt H., „O wciskaniu kitu”, transl. H. Pustuła, Wydawnictwo Czuły Barbarzyńca, Warsaw 2008. Lewenstein B.V., "Magazine Publishing and Popular Science After World War II", American Journalism 1989, No. 6 (4), pp. 218-234.

\footnotetext{
${ }^{9}$ Aristotle, „Etyka nikomachejska”, transl. D. Gromska, Państwowe Wydawnictwo Naukowe, Warsaw 1956, I.3.1094b, 23-30.
} 
Lewenstein B.V., "The Meaning of 'Public Understanding of Science' in the United States after World War II”, Public Understand Science 1992, No. 1, pp. 45-68.

Mardikian J., Vecchioli L., "Popular Literature vs. Scholarly Peer-Reviewed Literature. What's the Difference?", http://www.libraries.rutgers.edu/rul/indexes/scholarly_articles.shtml [access: 23.03.2010].

http://en.wikipedia.org/wiki/Scientific_American [access: 26.02.2015].

http://pl.wikipedia.org/wiki/Popularyzacja_nauki [access: 27.03.2015].

Jakub Z. Lichański

\section{The Rhetoric of Popular Science Texts. Scientific American Magazine as a Typical Example}

\section{(Summary)}

The aim of the study is to describe the relationship between rhetoric and popular science texts. Scientific American magazine is taken as an example. In conclusion, the author suggests that the rhetoric of popular science texts rests on the presentation of a problem, avoiding controversy in the presentation of research issues, avoiding modal forms and the use of multiple elements of visual rhetoric.

This article contains brief historical information about the development of the magazine Scientific American.

Keywords: popular science texts, rhetoric, rhetorical criticism, visual rhetoric, Scientific American. 